\title{
エアウェイスコープの開発コンセプトと声門視認
}

エアウェイスコープ開発は2003年に遡る。第 31 回 日本救急医学会総会・学術集会で “安全かつ確実な気 道確保のための新しい装置の開発”と題して, プロト タイプ1を報告した ${ }^{1)}$ 。その際, 開発コンセプトとし て以下の 4 点を提示した。(1)気道確保 (挿管)をより確 実にする。(2)安全な気道確保をコメディカルスタッフ にも可能にする。(3)抻管対象患者を広げる (頸損患者 も対象にする)。(4)気道確保の客観的な検証を可能に する。そして, それぞれのコンセプトを具体化するた めに, 高い声門視認性を持ち, 容易に使用可能であり, 頸部伸展不要で, 複数者による確認が可能であること などが新機器に必要な機能であると考えた。以来, 4 世代のプロトタイプ開発を経て, 2006年認可のエア ウェイスコープに発展している2)(Fig. 1)。従って, エアウェイスコープの高い声門視認性は, 開発当初か らの最優先機能である。小径 charge coupled device (CCD) イメージセンサーをブレード先端に配置する ことで, 十分な明るさと高精細画像を得ることが可能 となっており, ブレード先端の喉頭蓋展開板は舌根及 び喉頭蓋を押し上げ, 観察可能な空間をつくり出す。 CCDの光軸はブレードに対して内側に 20 度傾斜し, 気管チューブの挿入方向と前方で交差し, 交点にター ゲットマークが配置されている。これらの設計はすべ て, エアウェイスコープの高い声門視認性を確保する とともに, 容易かつ安全に気管挿管が達成できること を目的としている。

気管チューブと CCDの相対的な位置関係は開発当 初に議論された。“理論的にはブレード, CCD, 気管 チューブのすべてが同軸上にあることが気管挿管の確 実性という観点から望ましいのではないか”，または, “完全な同軸でなくても同一矢状面内にそれぞれを配 置すればよいのではないか”との意見があった。しか し, 前者のCCD とチューブの完全同軸の代表例であ るファイバースコープ方式では, “器械が大きくなり すぎ, 臨床の現場では使いづらいのではないか”, また, 後者のようにCCDとチューブを同一矢状面に配置す ると, “ブレード先端が厚くなりすぎるのではないか” と推測され, 最終的には, CCDとチューブを左右に配 置し, 従来のマッキントッシュ喉頭鏡に準じて非鏡像
対称の構造になった。

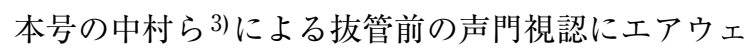
イスコープが有効であるという論文は, 抜管後の喉頭 浮腫が致命的気道閉塞を起こし得るという事実から, 抜管前に非侵襲的かつ客観的に喉頭観察を行いたいと いう麻酔科医の専門的モチベーションに基づいている と理解した。全身麻酔患者 10 例を対象に, 気管チュー ブ抜去前に, エアウェイスコープを用いて確認を行っ たところ, 声門の視認率は $100 \%$ でり, チューブの 死角を除いて非常に広い視野で喉頭の確認ができた一 方, エアウェイスコープによる確認の前後では, 確認後に 有意に心拍数, 血圧の上昇を認めたと報告している。

エアウェイスコープを用いた声門視認率について は, いくつかの報告がある。Asaiらは, 100例の外科 手術前の全身麻酔後にエアウェイスコープを用いて気 管扦管を行ったところ, 歯牙損傷の可能性があり中途 で挿管を断念した 1 例を除く99例で, 声門を完全に視 野に捉えることが可能で, 気管挿管を達成できたと報 告している4)。また, Suzukiらはエアウェイスコープ を用いて気管挿管を試みた 320 例の臨床報告をしてい る。それによると, マッキントッシュ喉頭鏡では Cormack Lehane分類でグレード3ないし4であった 46例で, エアウェイスコープの使用により，45例がグ レード 1 に, 1 例がグレード $2 \mathrm{a}$ に改善し, 結果的に $96 \%$ が一回目の手技によって気管挿管に成功し, 残る $4 \%$ も回目で気管挿管が達成されている5)。また, マッキントッシュ喉頭鏡では気管挿管が困難な, いわ ゆる挿管困難症例において, エアウェイスコープを用 いることによって声門が視認可能となり, 挿管を達成 できたという報告もいくつかなされている6) 8)。こ のように, 手術室での気管抻管時のエアウェイスコー プの高い声門視認性は既に確実となりつつある。中村 らは, この声門視認性を将来的には手術室だけではな く集中治療室や一般病棟でも活用し, 結果的に気道合 併症の減少を期待していると推察できる。個人的な経 験であるが, 病棟での気管チューブ入れ替えの際に, あらかじめ新しいチューブをエアウェイスコープに装 着し, 既に挿入されているチューブ及び喉頭を確認し た状態でチューブの入れ替えを行っている。このよう 


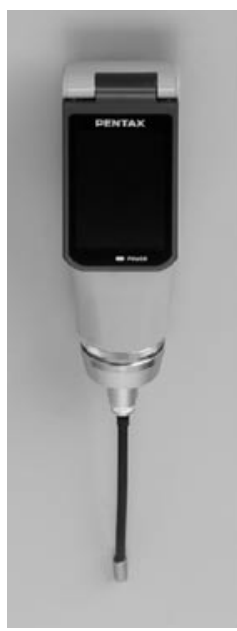

(a)

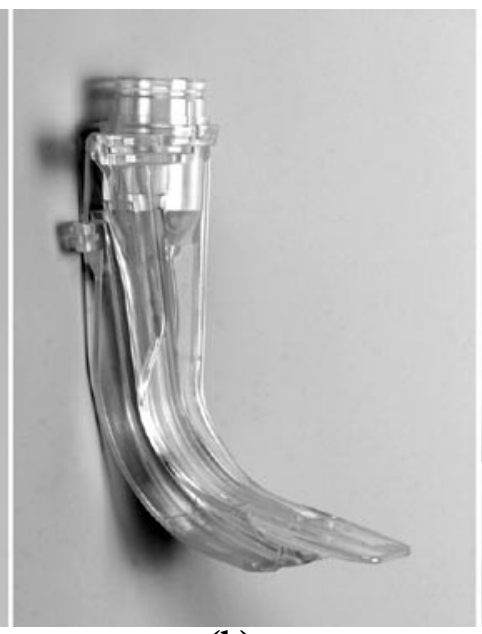

(b)

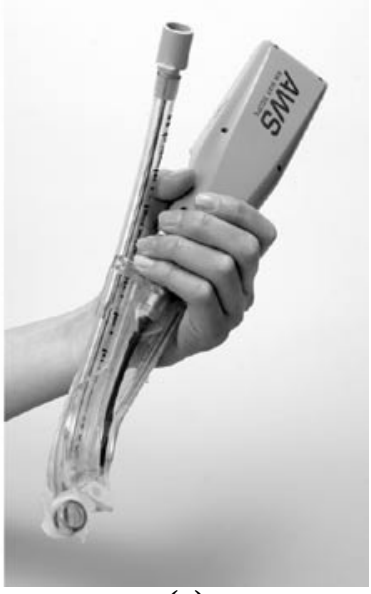

(c)

Fig. 1 Components of the AirWay Scope

Pictures showing components of the AirWay Scope (PENTAX-AWS outside Japan) and its overview. Two AA batteries activate a 2.4-inches full-colored monitor and a charge coupled device (CCD) image sensor with light-emitting diodes (LEDs), both in the main body of the PENTAX-AWS (a). The Intlock (P-Blade outside Japan), made from polycarbonate plastic, is designed to accurately guide a tracheal tube into the glottis (b). The P-Blade and tracheal tube are set within the main body prior to the intubation procedure (c).

にすることで抜管後に気道を見失う危険性や，気道合 併症が減少する可能性があると感じている。また, Sadamoriらは, エアウェイスコープを用いれば心蔵 マッサージを中断することなく気管挿管が可能である と報告しており 9), エアウェイスコープの応用範囲は, 手術室から集中治療室, 病棟, 救急室, 院外へと広がっ ていく可能性が示唆されている。

中村らの研究に敬意を表するとともに, 本邦発の工 アウェイスコープの有用性が, 今後も多方面で医学的 根拠をもって証明され, 気道確保はもちろん, 結果的 に救命処置の一助になることを願ってやまない。そし て, 既に多く寄せられている小児用ブレードの開発や 本体のスリム化などの希望に早急に応えていくこと も, 開発者の責務であると考えている。

$$
\begin{aligned}
& \text { 小山 淳一 } \\
& \text { 伊那中央病院脳神経外科 } \\
& \text { ( T 396-8555 長野県伊那市小四郎久保 } 1313 \text { 番地 } 1 \text { ) }
\end{aligned}
$$

\section{Development concepts of PENTAX-AWS and glottis visualization}

Key words: (1) development concepts, (2) PENTAX-AWS, (3) glottis visualization

Jun-ichi Koyama

Department of Neurosurgery, Ina Central Hospital 1313-1 Koshirokubo, Ina, Nagano 396-8555, Japan
J Jpn Soc Intensive Care Med. 2009;16:11 12.

\section{文 献}

1) 小山淳一, 高砂浩史, 岩下具美, 他. 救急時の気道確保を 支援する装置の開発 一エアウェイスコープ／プロトタイ プ1一。 日臨救医誌. 2005;8:341-2.

2) Koyama J, Aoyama T, Kusano Y, et al. Description and first clinical application of AirWay Scope for tracheal intubation. J Neurosurg Anesthesiol. 2006;18:247-50.

3) 中村隆治, 楠 真二, 河本昌志. エアウェイスコープで抜 管前の声門視認が可能か？日集中医誌. 2009;16:77-8.

4) Asai T, Enomoto Y, Shimizu K, et al. The PENTAX-AWS video-laryngoscope: the first experience in one hundred patients. Anesth Analg. 2008;106:257-9.

5) Suzuki A, Toyama Y, Katsumi N, et al. The PENTAXAWS rigid indirect video laryngoscope: clinical assessment of performance in 320 cases. Anaesthesia, 2008;63: 641-7.

6) 鈴木昭広, 林 大, 国沢卓之, 他. エアウェイスコープで 挿管し得たCormack分類 4 度の挿管困難 2 症例. 臨麻. 2007;31:853-6

7) 鈴木昭広, 黒澤 温, 国沢卓之, 他. エアウェイスコープ とスタイレットスコープで気道確保を行った巨大甲状腺腫 瘍の 1 例。臨麻. 2007;31:43-7.

8) 上嶋浩順, 浅井 隆, 新宮 興, 他. エアウェイスコープ にブジーを併用し気管挿管が可能であった症例. 麻酔. 2008;57:82-4.

9) Sadamori T, Kusunoki S, Ishida M, et al. Video laryngoscopy for emergency tracheal intubation during chest compression. Resuscitation. 2008;77:155-6. 